\title{
Contents, Vol. 181, 1980
}

Index Vol. 181,1980

No.1

Original Paper $\cdot$ Travaux originaux $\cdot$ Originalarbeiten

Format-Filled Detail Photographs with the Kowa RC-W Retinal Camera

Aan de Kerk, A.; Deutman, A., and Nouhuys, E. van 1

Tokyo Medical College Test in Acquired Dyschromatopsia

Pinckers, A 7

Effektivität unterschiedlicher Tonometer-Desinfektionsverfahren (Effectivity of Different

Methods for Desinfection of Applanation Tonometer Prisms)

Wizemann, A 13

Color Vision and Age

Pinckers, A 23

Pathology of Ocular Tissues in Amyloidosis

Campos, E.C.; Melato, M.; Manconi, R., and Antonutto, G 31

Tolerance of Normal Rabbit Eyes to the Antineoplastic Carmustine

Liu, H.S.; Perry, H.D., and Refojo, M.F

Recovery from Macular Photostress and Slow Retinal Potentials in Cured Retinal Detachment

Krastel, H. and Alexandridis, E

Rebound-Nystagmus (Rebound Nystagmus)

Hamann, K.-U 53

Book Review 58

Announcements

59

No. 2

Original Paper · Travaux originaux $\cdot$ Originalarbeiten

Congenital Glaucoma and Its Inheritance

Francois, J 61

Amoebic Keratitis

Hamburg, A. and De Jonckheere, J. F 74

Cryotreatment in Proliferative Diabetic Retinopathy. Long-Term Results

Oosterhuis, J. A. and Bijlmer-Gorter, H 81

Results and Complications of Surgery for Retinal Detachment with a Macular Hole

Amemiya, T. and Iida, T 88

Late Extraocular Tumours in Retinoblastoma Survivors

Francois, J.; Sutter, E.de; Coppieters, R., and Bie, S.de

Les relations sensorielles binoculaires dans le strabisme divergent et le strabisme convergent. Etude clinique -Thérapeutique - Pronostic (The Binocular Sensory Relationship in Divergent and Convergent Strabism. Clinical Study - Therapy - Prognostic)

Pigassou-Albouy, R 100 
Morphometric Study of the Hydration Capacity of the Scleral Trabeculum after Hyaluronidase Action

Francois, J. and Victoria-Troncoso, V 108

Mechanical Behavior of the Iris-Lens-Zonule-Ciliary Body Systems

Arciniegas, A.; Amaya, L.E., and Vicioso, G 114

IV Contents

Letter to the Editor 118

Book Reviews $\cdot$ Livres nouveaux $\cdot$ Buchbesprechungen $\quad 119$

No. 3-4

Original Paper $\cdot$ Travaux originaux $\cdot$ Originalarbeiten

Eye Problems of the Elderly

Blodi, F.C 121

Congenital Obstruction of the Lacrimal Passages in Five Consecutive Generations

Moro, F.; Li Volti, S.; Tomarchio, S.; Pavone, L.; Martorina, M, and Mollica, F 129

Oxatomide Effects in Follicular Conjunctivitis of Presumed Allergic Cause. A Double-Blind

Evaluation

Blockeel, J. and Leuridan, 0133

Die Rasteräquidensitometrie zur objektiven Beurteilung der Helligkeitsverteilung auf der Papille (Screening Equidensitometry for the Objective Evaluation of Optic Disc Pallor)

Rochels, R '. 139

La prevention du décollement de rétine de $\Gamma$ aphaque par photocoagulation au laser à $\Gamma$ argon. A propos de 600 cas (Prophylactic Treatment of Aphakic Retinal Detachment by Argon Laser

Photocoagulation. Study on 600 Cases)

Saracco, J. B.; Estachy, G.M.; Gastaud, P. et Maymard, 1142

Long-Term Evaluation of Temporary Transconjunctival Buckling for Retinal Detachment

Ciurlo, G. and Rossi, P. L 149

Medulloepithelioma Arising from the Posterior Pole

Hamburg, A 152

Vorübergehende Netzhautablösung und Hyposphagma bei einem Patienten mit Non-Hodgkin-

Lymphom vom T-Zell-Typ (Transient Retinal Detachment and Hyposphagma in a Patient with

Non-Hodgkin Lym-phoma of the T Cell Type)

Pau, H. und Schneider, W 160

The Electrooculogram and Its Interindividual Variability

Zonneveldt, A. and Lith, G. van 165

ERG in Amaurosis fugax, Depending on the Position of the Body. A Case Presentation

Rover, J 170

Change in Human Electroretinography Associated with Thioridazine Administration

Miyata, M.; Imai, H; Ishikawa, S., and Nakajima, S 175

Orbital Pseudotumour

Gutierrez Diaz, A.; Sanz Lopez, A.; Alonso Porres, M. J.; Fernandez Zorilla, M. J.; Moreno

Gozalvez,

T., and Fuente Gomez, M. de la

181

Optociliary Veins Associated with Meningioma of the Optic Nerve Sheath

Tsukahara, S.; Kobayashi, S.; Nakagawa, F., and Sugita, K 188

Ocular Coloboma with Congenital Heart Disease in the Absence of Chromosomal Abnormalities

Magli, A.; Ambrosio, G., and Francois, J 195 
Blindness Due to Sellar Region Tumour-Caused Apoplexy. Visual Field Investigation Helps the Diagnosis

Yuanxiu, L 203

Myotonic Dystrophy: Pathological Study of the Eyes

Meyer, E.; Navon, D.; Auslender, L., and Zonis, S 215

Long-Term Treatment with Timolol Ophthalmic Solution in Open-Angle Glaucoma

Demailly, P. and Arrata, M 221

Psychotic Reaction in an Adult after Topical Cyclopentolate

Shihab, Z. M 228

Contents

$\mathrm{V}$

Rotations oculaires et reflets coméens (Ocular Rotation and Corneal Reflexes)

Paliaga, G.P.; Ghisolfi, A.; Giunta, G. et Decarli, A 231

Book Reviews $\cdot$ Livres nouveaux $\cdot$ Buchbesprechungen

No. 5

Original Paper $\cdot$ Travaux originaux $\cdot$ Originalarbeiten

Intraocular and Episcleral Melanoma Treated with Beta Radiation (106Ru/106Rh)

Lommatzsch, P. K 241

Chromosome 13 Deletion Syndrome: Report of a New Case and Discussion of the Different

Etiologic Patterns of Retinoplastoma

Lungarotti, M.S.; Mariotti, G.; Quarta, C; Delogu, A., and Fiore, C 245

La rétinite centrale séreuse, Considerations étiopathogéniques et cliniques (avec 1 planche en couleur). (Central Serous Retinopathy. Etiopathogenetic and Clinical Considerations) (with 1 Color Plate)

Balacco-Gabrieli, C; Asciano, F.; Reibaldi, A., and Santoro, M

251

Retinal Detachment in Retrolental Fibroplasia

Starzycka, M.; Ciechanowska, A., and Gergovich, A

261

Computer Image Analysis of the Optic Disc

Pe'er, J. and Zajicek, G 266

Experience with Management of Glaucomas by Isoglaucon

Rozsíval, P.; Hrochová, J., and Rehák, S 271

Proceedings $\cdot$ Comptes rendus $\cdot$ Verhandlungsberichte

Netherlands Ophthalmological Society, 174th Annual Meeting $1980 \quad 277$

Book Reviews - Livres nouveaux · Buchbesprechungen 300

No. 6

Original Paper $\cdot$ Travaux originaux $\cdot$ Originalarbeiten

Inheritance of Endothelial Dystrophy of the Cornea

Krachmer, J.H.; Bucher, K.D.; Purcell, J. J., Jr.; Young, C.W

Blood Staining of the Cornea in Hansen's Disease. A Light- and Electron-Microscopic Study

(with 1 Color Plate)

Yoshimura, M.; Sameshirma, M.; Fujita, S.; Ohba, N

Lacrimal Lysozyme Alterations in Experimental Protein Deficiency

Ratnakar, K.S.; Kanta, R.C.; Mehta, U.; Amoji, S.D 320

Bilateral Abducens Nerve Palsy

Limnaios, E. E.; Papageorgiou, C. T 326

Ataxia Telangiectasia 
Nemet, P.; Godel,V.; Reider-Groswasser, I.; Lazar, M

Ocular Complications of Juvenile Angiofibroma

Bonavolontà, G.; Villari, G; Rosa, G. de; Sammartino, A 334

Morphometric and Electrophysiologic Study of the Photoreceptors in the Horse

Francois, J.; Wouters, L.; Victoria-Troncoso, V.; Rouck, A. de; Gerven, A. van

Announcements $\boldsymbol{C}$ Communications $\cdot$ Ankündigungen 350

A. Author Index 351

Subject Index 353 